\title{
West Java local rice panicle branching architecture
}

\author{
Fyannita Perdhana*, Tri Hastini, and Iskandar Ishaq \\ West Java Assessment Institute for Agricultural Technology, J1. Kayuambon 80 Lembang Bandung \\ Barat 40391, Indonesia
}

\begin{abstract}
As local varieties of rice have a very important role as a source of valuable traits in developing high yielding variety through plant breeding programs, it is needed to be characterized. Panicle branching characterization is one of the efforts to understand local varieties of rice characteristics more. We have observed thirtheen characters of panicle branching on 24 West Java local rice varieties. Five panicles of each varieties as accession was observed and statistical analysed. Tukey's Honest Significant Difference (HSD) test showed differences among accessions in all panicle branching characteristics observed. Based on Principles Component Analysis (PCA), the panicle branching characters observed generally showed the same direction, but among them were not always to be correlated. In the result of clustering based on the ward linkage method, the accessions were divided into two clusters. The first one had 8 members, and the second one had 16 members. The cophenetic correlation coefficient was 0.60 , indicated that the clustering through standardized value was faithfully enough to represent the original distances. The result of this research can provide the information for breeder in selecting rice genotypes which have more seeds per panicle as parent in assembling new high yielding rice varieties.
\end{abstract}

\section{Introduction}

Local variety was defined as one which cultivated by subsistence farmer from one generation to the next and it had adapted in a specific area. The local varieties are used by the farmers as the main component of their cultivation based on their knowledge of adapted varieties and quality. The local varieties have valuable traits which can represent the gene pool. So, it is important to collect and to make a document of such varieties as a source of valuable traits in developing high yielding variety through plant breeding program [1]. Chaudary et al. [2] stated that indigenous rice varieties which traditionally cultivated and maintained by the farmers had high level of diversity in genetic, so it could be used as a source in improving yield, performance of agronomic, and resistance to pest and pathogen.

Characterization is the activity to describe accessions, establish accessions' characteristic and classified it into groups based on relationship among traits, among accessions, and among geographic groups [3]. The characterized accesssions could be

\footnotetext{
* Corresponding author: fyannita@gmail.com
} 
grouped into several clusters based on morpho-physicochemical characters [4] morphoagronomic characters [5] or other characters.

West Java has abundant local rice varieties and grouped as landraces. Although most of the field area was changed with new varieties, there were still found local varieties. Local varieties of rice commonly showed long-harvest date (4-6 months), tall plant height (126 $-177 \mathrm{~cm})$, and less number of productive tiller $(<14)$. Based on their characteristics, local rice varieties belong to Javanica rice. Javanica rice was characterized by awn on its grains, long-harvest date, tall plant height, and less number of tiller [6].

As the panicle branching of rice has the important role in determining the number of grain and affect to the yield, the observation and characterization of panicle structure is very important. Nurhasanah et al. [7] declared that local rice variety which had the dense panicle could be used as promising germplasm to create high yielding varieties. This study was aimed to understand the characteristics of panicle branching structure and clustering of local rice varieties in West Java.

\section{Materials and methods}

Genetic material were observed originated from exploration in the previous year, which some were taken from rejuvenation and others from observation planting. There were 24 local rice varieties (accessions) as genetical material as shown at Table 1. Five panicles of each accession were observed and each was taken as replication because of the limitation of panicle number collected.

Table 1. West Java local rice varieties as genetic material

\begin{tabular}{|c|c|c|}
\hline Accession number & Accession name & Origin \\
\hline L01 & Mujaer Mundur & Cianjur \\
\hline L02 & Tusir Super & Sumedang \\
\hline L03 & Jalur & Sumedang \\
\hline L04 & Sri Dewi & Bandung \\
\hline L05 & Narkotik & Garut \\
\hline L06 & Jadul & Garut \\
\hline L07 & Mori bodas & Bandung \\
\hline L08 & TSP & Cianjur \\
\hline L09 & Marahmay & Cianjur \\
\hline L10 & Morneng & Cianjur \\
\hline L11 & GH Panjang & Bandung \\
\hline L12 & Torondol & Sumedang \\
\hline L13 & Apel Bodas & Bogor \\
\hline L14 & Osog & Garut \\
\hline L15 & Sri Kuning & Bandung \\
\hline L16 & Tusir & Sumedang \\
\hline L17 & Menet & Garut \\
\hline L18 & Ketan Kidang & Sukabumi \\
\hline L19 & Panak & Sukabumi \\
\hline L20 & Buntut Nyiruan & Sukabumi \\
\hline L21 & Cere Cikapundung & Sukabumi \\
\hline L22 & Cere batu & Sukabumi \\
\hline L23 & Beureum Beunying & Sukabumi \\
\hline L24 & Bonbon & Sukabumi \\
\hline
\end{tabular}

The observation was carried out in West Java Assessment Institute for Agricultural Technology (West Java AIAT). The characters observed were panicle length (PL), node number $(\mathrm{NN})$, number of grain number per panicle (NGP), number of primary panicle 
branches (NPB), number of secondary panicle branches (NSB), number of tertiary panicle branches (NTB), primary branches length (PBL), secondary branches length (SBL), number of grain per primary branches (GPB), number of grain per secondary branches (GSB), total length of primary branches (TLPB), total length of secondary branches (TLSB), and number of secondary branches per primary branches (NSBperPB). The observation of each character was presented at Table 2 .

Table 2. The panicle branching characters observed of local rice varieties

\begin{tabular}{|c|c|}
\hline Characters & The measurement manner of panicle branches characters \\
\hline PL & is measured from panicle neck to the tip of panicle \\
\hline NN & is counted the number of nodes which a group of primary braches grow \\
\hline NGP & is counted the total number of filled and unfilled grains per panicle \\
\hline NPB & is counted the number of primary branches per panicle \\
\hline NSB & is counted the number of secondary branches per panicle \\
\hline NTB & is counted the number of tertiary branches per panicle \\
\hline PBL & is measured from the base to the tip of primary branch \\
\hline SBL & is measured from the base to the tip of secondary branch \\
\hline GPB & is counted the number of grains per primary branch \\
\hline GSB & is counted the number of grains per secondary branch \\
\hline TLPB & is the total length of primary branches per panicle \\
\hline TLSB & is the total length of secondary branches per panicle \\
\hline SBperPB & is counted the number of secondary branches per primary branch \\
\hline
\end{tabular}

To find out the information about homogeneity of variance and distribution, data were analysed using Bartlett's test for homogeneity of variance and Shapiro-Wilk test for distribution. Further, data were ANOVA analysed and performed by Statistical Tool for Agricultural Research (STAR Nebula). The significant results were continued by further analysis using Tukeys's Honest Significant Difference (HSD) Test. The R statistics 4.0.5 version was used to perform Agglomerative Hierarchical Clustering (AHC) and Principle Component Analysis (PCA). The method of AHC was based on the ward method, and data were standardized before analysed.

\section{Result and discussion}

Based on Bartlett's test, the characters of number of primary panicle branches, number of tertiary panicle branches, secondary branches length, and number of grain per secondary branches were heterogenous. While based on Spahiro Wilk test, the characters of number of tertiary panicle branches and secondary branches length were not normally distributed (Table 3). As the parametric statistic requires the assumption of homogeneity of variance and normality distributed, the characters of number of primary panicle branches, number of tertiary panicle branches, secondary branches length, and number of grain per secondary branches were discarded for ANOVA analysis. Normality and equal of variance assumption in the comparison of three or more groups useful for decreasing Type I error in analysis result [8].

There were differences among accessions in panicle branching characteristics. The accession which had the longest panicle was Sri Kuning and the shortest was Mujaer Mundur, each was $32.3 \mathrm{~cm}$ and $22.7 \mathrm{~cm}$ respectively. The accessions of Tusir Super, Sri Dewi, Jadul, Marahmay, Morneng, Ketan Kidang, and Cere Cikapundung were not significantly different with Sri Kuning. On the other hand, although its panicle was shortest, Mujaer Mundur had the most number of node on its panicle (11 nodes). The lowest number of node observed in the accessions of Jadul, TSP, Marahmay, and Menet, those were not significantly different each other (Table 4). 
Table 3. Descriptive statistics of panicle branching characters observed of West Java rice local varieties

\begin{tabular}{|c|c|c|c|c|c|c|}
\hline Characters & Min & Max & Mean \pm StdDev & CV & $\begin{array}{c}\text { Bartlett's } \\
\text { test }\end{array}$ & $\begin{array}{c}\text { Saphiro Wilk } \\
\text { test }\end{array}$ \\
\hline Panicle length & 19.00 & 34.60 & $27.29 \pm 2.93$ & 10.74 & 0.0624 & 0.5201 \\
\hline Node number & 5.00 & 11.00 & $8.61 \pm 1.54$ & 17.84 & 0.4732 & 0.4499 \\
\hline $\begin{array}{c}\text { Number of grain } \\
\text { number per panicle }\end{array}$ & 50.00 & 426.00 & $228.07 \pm 72.13$ & 31.63 & 0.2673 & 0.9881 \\
\hline $\begin{array}{c}\text { Number of primary } \\
\text { panicle branches }\end{array}$ & 6.00 & 20.00 & $11.64 \pm 2.45$ & 21.03 & $\mathbf{0 . 0 0 4 9}$ & 0.0610 \\
\hline $\begin{array}{c}\text { Number of secondary } \\
\text { panicle branches }\end{array}$ & 3.00 & 74.00 & $42.61 \pm 14.57$ & 34.20 & 0.3542 & 0.6615 \\
\hline $\begin{array}{c}\text { Number of tertiary } \\
\text { panicle branches }\end{array}$ & 0.00 & 34.00 & $3.21 \pm 5.20$ & 161.57 & $\mathbf{0 . 0 0 0 0}$ & $\mathbf{0 . 0 0 0 0}$ \\
\hline $\begin{array}{c}\text { Primary branches } \\
\text { length }\end{array}$ & 7.36 & 15.89 & $11.92 \pm 1.68$ & 14.07 & 0.1296 & 0.3036 \\
\hline $\begin{array}{c}\text { Secondary branches } \\
\text { length }\end{array}$ & 2.22 & 4.28 & $3.09 \pm 0.43$ & 13.89 & $\mathbf{0 . 0 0 3 4}$ & $\mathbf{0 . 0 4 5 3}$ \\
\hline $\begin{array}{c}\text { Number of grain per } \\
\text { primary branches }\end{array}$ & 6.25 & 35.50 & $19.77 \pm 5.41$ & 27.34 & 0.5610 & 0.9026 \\
\hline $\begin{array}{c}\text { Number of grain per } \\
\text { secondary branches }\end{array}$ & 2.92 & 5.51 & $3.78 \pm 0.47$ & 12.36 & $\mathbf{0 . 0 3 7 5}$ & 0.5365 \\
\hline $\begin{array}{c}\text { Total length of } \\
\text { primary branches }\end{array}$ & 52.70 & 221.40 & $138.40 \pm 31.64$ & 22.86 & 0.2841 & 0.3923 \\
\hline $\begin{array}{c}\text { Total length of } \\
\text { secondary branches }\end{array}$ & 8.70 & 253.50 & $133.06 \pm 50.91$ & 38.26 & 0.7570 & 0.8918 \\
\hline $\begin{array}{c}\text { Number of secondary } \\
\text { branches } \\
\text { per primary branches }\end{array}$ & 1 & 5.69 & $3.73 \pm 1.01$ & 27.19 & 0.6905 & 0.4564 \\
\hline
\end{tabular}

Bold letter indicated significant value ( $p$-value $\leq 0.05$ ), population was heterogenous, and/or data was not normally distributed

In the character of grain number per panicle, Marahmay showed the most $(330.8$ grains), was not significantly different with Tusir Super, Jalur, Sri Dewi, Jadul, Mori Bodas, Morneng, Torondol, Apel Bodas, Osog, Sri Kuning, Tusir, and Ketan Kidang. While the lowest number of number grain per panicle was showed on Cere Batu accession. The accessions which have more grains per panicle can be recomended as parent for assembling new plant types of rice. High grain yield can be achieved through breeding program using rice with more seed in the panicle. So, rice breeders have a chance to assembly new plant type rice with spikelet number more than 250 seeds [9]. The accession of Morneng had the most number of secondary panicle branch (61.6 branches). The other thirteen accessions, namely Tusir Super, Jalur, Sri Dewi, Jadul, Mori Bodas, Marahmay, GH Panjang, Torondol, Apel Bodas, Osog, Sri Kuning, Tusir, and Panak were not significantly different.

There was also differences in the character of primary panicle branches length. The longest primary panicle branches length was $14.4 \mathrm{~cm}$ and $14.6 \mathrm{~cm}$ respectively, showed in the accession of Sri Dewi and Jadul. Both were not significantly different. There were also accessions which had long primary panicle branches length, i.e Tusir Super, Jalur, Mori Bodas, Marahmay, Morneng, GH Panjang, Apel Bodas, and Cere Cikapundung. All the accessions above were not significantly different with Sri Dewi and Jadul based on HSD test. Number of grain per primary panicle branch was range from $10.6-27.8$. The highest number of grain per primary panicle branch was in the accession Marahmay, but it was not significantly different with Tusir Super, Jalur, Sri Dewi, Narkotik, Jadul, Mari Bodas, Morneng, GH Panjang, Apel Bodas, Osog, and Tusir. 
Primary branches per panicle in the accessions observed showed vary in total length $(90.3-174.4 \mathrm{~cm})$. The longest total length of primary branches per panicle was Sri Kuning, and the shortest was Cere Batu. The majority of the accessions observed showed had long total length of primary branches per panicle, i.e Tusir Super, Jalur, Sri Dewi, Mori Bodas, TSP, Marahmay, Morneng, GH Panjang, Torondol, Osog, Tusir, Menet, Ketan Kidang, Panak, and Cere Cikapundung. While total length of secondary branches per panicle was range between $47-197.5 \mathrm{~cm}$. The longest was in Mari Bodas, and the shortest was Cere Batu. Other accessions which had long of total length of secondary branches per panicle were Tusir Super, Jalur, Sri Dewi, Jadul, Marahmay, Morneng, GH Panjang, Apel Bodas, Osog, Tusir, Panak, and Cere Cikapundung.

The number of secondary branches per primary branch was ranging from $1.9-4.9$. The three top of accessions which had most number of secondary branches per primary branch were Sri Dewi, Marahmay, and Morneng, while other accessions which was not showed significantly different with the three accessions above were Mujaer Mundur, Tusir Super, Jalur, Narkotik, Jadul, Mori Bodas, GH Panjang, Apel Bodas, Osog, and Tusir. The significant differences in the characters observed indicated that there was wide variation among the accessions tested [10]. Akinwale et al. [11] reported that study in agronomic characters of rice revealed that most characters observed exhibited wide range of variability. It seems that rice panicle branching characters also had the same trend.

Table 4a. The average of panicle branching characteristic of West Java rice local varieties

\begin{tabular}{|c|c|c|c|c|c|c|c|c|c|c|}
\hline Varieties & PL & & $\mathbf{N N}$ & & GNP & & NSB & & PBL & \\
\hline Mujaer Mundur & $22.7 \pm 2.0$ & $\mathrm{i}$ & $11.0 \pm 0.0$ & $\mathrm{a}$ & $207.8 \pm 72.1$ & c-h & $38.4 \pm 6.7$ & d-h & $12.0 \pm 0.6$ & b-f \\
\hline Tusir Super & $28.9 \pm 0.8$ & a-e & $9.4 \pm 0.9$ & $a b$ & $282.6 \pm 32.0$ & a-c & $59.4 \pm 8.9$ & $\mathrm{ab}$ & $12.9 \pm 0.6$ & a-e \\
\hline Jalur & $27.4 \pm 1.3$ & b-g & $8.0 \pm 1.2$ & $\mathrm{ab}$ & $266.6 \pm 56.5$ & $a-f$ & $51.8 \pm 9.6$ & a-e & $12.7 \pm 0.6$ & a-d \\
\hline Sri Dewi & $29.2 \pm 1.6$ & a-e & $8.0 \pm 1.9$ & $a b$ & $276.6 \pm 58.6$ & a-d & $51.0 \pm 9.6$ & a-e & $14.6 \pm 1.0$ & $\mathrm{a}$ \\
\hline Narkotik & $25.2 \pm 0.9$ & $e-i$ & $8.2 \pm 1.3$ & $\mathrm{ab}$ & $215.4 \pm 18.9$ & c-h & $39.4 \pm 3.6$ & c-h & $12.2 \pm 0.7$ & b-f \\
\hline Jadul & $29.6 \pm 1.4$ & a-d & $7.4 \pm 0.6$ & $\mathrm{~b}$ & $234.2 \pm 51.8$ & a-h & $42.6 \pm 10.9$ & a-h & $14.4 \pm 0.9$ & $\mathrm{a}$ \\
\hline Mori bodas & $27.8 \pm 1.5$ & b-f & $9.2 \pm 0.8$ & $\mathrm{ab}$ & $288.8 \pm 34.2$ & $a-c$ & $57.2 \pm 6.6$ & $a-d$ & $12.8 \pm 0.5$ & a-d \\
\hline TSP & $23.4 \pm 1.6$ & g-i & $7.2 \pm 0.8$ & $\mathrm{~b}$ & $166.0 \pm 32.16$ & $f-i$ & $27.0 \pm 7.6$ & g-i & $11.3 \pm 0.6$ & d-h \\
\hline Marahmay & $29.0 \pm 1.8$ & a-e & $7.6 \pm 1.7$ & $\mathrm{~b}$ & $330.8 \pm 81.51$ & $\mathrm{a}$ & $57.8 \pm 7.3$ & $a-c$ & $13.0 \pm 1.0$ & a-d \\
\hline Morneng & $29.8 \pm 1.7$ & a-c & $9.6 \pm 1.1$ & $a b$ & $317.8 \pm 61.8$ & $\mathrm{ab}$ & $61.6 \pm 10.6$ & $\mathrm{a}$ & $13.2 \pm 1.7$ & $a-c$ \\
\hline GH Panjang & $26.4 \pm 1.6$ & $c-i$ & $8.4 \pm 1.8$ & $a b$ & $227.2 \pm 32.3$ & b-h & $43.4 \pm 6.4$ & a-h & $13.4 \pm 0.9$ & a-c \\
\hline Torondol & $24.8 \pm 2.2$ & $f-i$ & $8.4 \pm 1.7$ & $\mathrm{ab}$ & $234.2 \pm 108.3$ & a-h & $44.0 \pm 22.5$ & $a-h$ & $10.4 \pm 1.2$ & f-h \\
\hline Apel Bodas & $28.0 \pm 1.0$ & b-f & $8.8 \pm 1.3$ & $\mathrm{ab}$ & $238.0 \pm 37.5$ & a-h & $45.0 \pm 7.0$ & a-h & $12.0 \pm 0.9$ & b-f \\
\hline Osog & $27.4 \pm 1.1$ & b-g & $7.8 \pm 1.9$ & $a b$ & $257.2 \pm 58.6$ & a-g & $46.0 \pm 10.5$ & $a-g$ & $13.7 \pm 0.8$ & $\mathrm{ab}$ \\
\hline Sri Kuning & $32.3 \pm 2.9$ & $\mathrm{a}$ & $8.4 \pm 1.8$ & $a b$ & $231.6 \pm 68.1$ & a-h & $47.2 \pm 14.3$ & a-f & $10.7 \pm 0.4$ & e-h \\
\hline Tusir & $27.9 \pm 1.6$ & b-f & $9.4 \pm 0.9$ & $a b$ & $273.0 \pm 45.9$ & a-e & $54.2 \pm 11.2$ & a-e & $12.3 \pm 0.5$ & b-f \\
\hline Menet & $23.2 \pm 0.6$ & hi & $7.4 \pm 1.1$ & $\mathrm{~b}$ & $196.8 \pm 39.0$ & $c-i$ & $36.0 \pm 8.8$ & e-h & $11.5 \pm 0.9$ & c-g \\
\hline Ketan Kidang & $31.0 \pm 2.2$ & $\mathrm{ab}$ & $9.2 \pm 1.3$ & $a b$ & $172.0 \pm 58.3$ & $e-i$ & $30.0 \pm 11.4$ & f-i & $11.2 \pm 0.9$ & d-h \\
\hline Panak & $28.2 \pm 1.2$ & b-f & $9.2 \pm 1.5$ & $a b$ & $263.8 \pm 45.2$ & $a-g$ & $46.4 \pm 10.4$ & $a-f$ & $10.4 \pm 0.5$ & f-h \\
\hline Buntut Nyiruan & $27.2 \pm 3.1$ & b-h & $8.6 \pm 1.8$ & $a b$ & $147.6 \pm 35.5$ & hi & $26.2 \pm 7.7$ & hi & $9.9 \pm 0.8$ & gh \\
\hline Cere Cikapundung & $28.5 \pm 0.7$ & a-f & $9.0 \pm 1.9$ & $a b$ & $206.8 \pm 53.5$ & c-h & $41.8 \pm 6.6$ & b-h & $12.9 \pm 0.3$ & a-d \\
\hline Cere batu & $25.3 \pm 4.4$ & $e-i$ & $8.0 \pm 1.9$ & $\mathrm{ab}$ & $97.6 \pm 40.4$ & $\mathrm{i}$ & $15.4 \pm 8.6$ & $\mathrm{i}$ & $9.8 \pm 1.8$ & gh \\
\hline Beureum Beunying & $25.7 \pm 1.6$ & d-i & $9.8 \pm 0.8$ & $\mathrm{ab}$ & $177.6 \pm 32.6$ & d-i & $30.8 \pm 6.9$ & $f-i$ & $9.6 \pm 0.8$ & gh \\
\hline Bonbon & $26.1 \pm 2.4$ & $c-i$ & $8.6 \pm 1.3$ & $a b$ & $163.6 \pm 30.0$ & g-i & $30.0 \pm 4.5$ & $f-i$ & $9.4 \pm 0.4$ & $\mathrm{~h}$ \\
\hline CV (\%) & 6.22 & & 16.03 & & 18.81 & & 18.89 & & 6.92 & \\
\hline
\end{tabular}

$\mathrm{GNP}=$ number of grain number per panicle;

$\mathrm{NSB}=$ number of secondary panicle branches;

$\mathrm{PBL}=$ primary branches length;.Value in the same colom which followed by the same letter was not significantly different based on Tukeys's Honest Significant Difference (HSD) Test 
Table 4b. The average of panicle branching characteristic of West Java rice local varieties (continued)

\begin{tabular}{|c|c|c|c|c|c|c|c|c|}
\hline Varieties & GPB & & TLPB & & TLSB & & \multicolumn{2}{|c|}{ NSB perPB } \\
\hline Mujaer Mundur & $19.8 \pm 3.3$ & b-h & $127.3 \pm 23.1$ & c-f & $121.3 \pm 25.3$ & $c-i$ & $3.7 \pm 0.6$ & a-g \\
\hline Tusir Super & $21.4 \pm 1.2$ & $a-h$ & $164.8 \pm 11.2$ & $a-c$ & $150.0 \pm 20.5$ & a-g & $4.5 \pm 0.4$ & $\mathrm{ab}$ \\
\hline Jalur & $23.3 \pm 3.8$ & a-e & $142.4 \pm 11.4$ & $a-e$ & $180.6 \pm 38.9$ & a-d & $4.5 \pm 0.6$ & $a b$ \\
\hline Sri Dewi & $26.7 \pm 4.0$ & $a b$ & $151.8 \pm 26.5$ & a-d & $190.9 \pm 36.4$ & $\mathrm{ab}$ & $4.9 \pm 0.6$ & $\mathrm{a}$ \\
\hline Narkotik & $20.8 \pm 2.0$ & a-h & $126.6 \pm 10.2$ & $c-f$ & $128.2 \pm 21.1$ & $b-i$ & $3.8 \pm 0.3$ & $a-f$ \\
\hline Jadul & $26.2 \pm 2.2$ & $a b$ & $128.3 \pm 25.2$ & b-f & $165.4 \pm 36.4$ & a-d & $4.7 \pm 0.2$ & $a b$ \\
\hline Mori bodas & $23.3 \pm 2.5$ & a-e & $158.6 \pm 9.3$ & $a-c$ & $197.5 \pm 28.7$ & $\mathrm{a}$ & $4.6 \pm 0.5$ & $a b$ \\
\hline TSP & $14.2 \pm 2.3$ & g-i & $133.3 \pm 25.2$ & $a-f$ & $83.9 \pm 26.4$ & $g-j$ & $2.5 \pm 0.4$ & $f-h$ \\
\hline Marahmay & $27.8 \pm 5.0$ & $\mathrm{a}$ & $153.6 \pm 23.6$ & a-d & $187.5 \pm 47.0$ & $a-c$ & $4.9 \pm 0.3$ & $\mathrm{a}$ \\
\hline Morneng & $25.3 \pm 5.1$ & $a-c$ & $166.2 \pm 18.6$ & $a-c$ & $181.1 \pm 43.4$ & $a-d$ & $4.9 \pm 0.9$ & $\mathrm{a}$ \\
\hline GH Panjang & $21.0 \pm 3.8$ & $a-h$ & $146.9 \pm 18.8$ & $a-d$ & $142.2 \pm 31.5$ & a-h & $4.0 \pm 0.8$ & $a-e$ \\
\hline Torondol & $17.1 \pm 5.4$ & $\mathrm{~d}-\mathrm{i}$ & $139.5 \pm 38.2$ & a-e & $124.3 \pm 73.8$ & $\mathrm{~b}-\mathrm{i}$ & $3.5 \pm 1.0$ & b-g \\
\hline Apel Bodas & $23.0 \pm 3.5$ & $a-f$ & $124.1 \pm 11.8$ & $c-f$ & $140.3 \pm 26.4$ & a-h & $4.4 \pm 0.7$ & $a-d$ \\
\hline Osog & $24.5 \pm 3.5$ & $a-d$ & $142.7 \pm 22.1$ & $a-e$ & $155.9 \pm 32.9$ & $a-e$ & $4.4 \pm 0.6$ & $a-c$ \\
\hline Sri Kuning & $15.9 \pm 2.4$ & $e-i$ & $174.4 \pm 53.9$ & $\mathrm{a}$ & $117.7 \pm 40.8$ & $\mathrm{~d}-\mathrm{i}$ & $3.1 \pm 0.4$ & $\mathrm{c}-\mathrm{h}$ \\
\hline Tusir & $21.6 \pm 2.2$ & $\mathrm{a}-\mathrm{g}$ & $155.0 \pm 12.0$ & $a-c$ & $152.5 \pm 30.4$ & a-f & $4.3 \pm 0.6$ & a-d \\
\hline Menet & $16.9 \pm 3.1$ & $e-i$ & $135.6 \pm 29.2$ & a-f & $117.7 \pm 32.0$ & d-i & $3.2 \pm 0.7$ & $\mathrm{c}-\mathrm{h}$ \\
\hline Ketan Kidang & $14.1 \pm 3.0$ & hi & $135.8 \pm 28.2$ & $a-f$ & $96.5 \pm 41.7$ & $e-j$ & $2.5 \pm 0.7$ & gh \\
\hline Panak & $16.4 \pm 2.0$ & $e-i$ & $173.6 \pm 21.8$ & $\mathrm{ab}$ & $135.2 \pm 36.7$ & $a-i$ & $3.0 \pm 0.5$ & $e-h$ \\
\hline Buntut Nyiruan & $15.2 \pm 2.2$ & g-i & $97.8 \pm 26.9$ & ef & $71.2 \pm 22.8$ & $\mathrm{ij}$ & $2.7 \pm 0.6$ & e-h \\
\hline Cere Cikapundung & $17.9 \pm 2.7$ & $c-i$ & $146.9 \pm 22.9$ & $a-d$ & $144.6 \pm 24.4$ & $\mathrm{a}-\mathrm{g}$ & $3.6 \pm 0.2$ & a-g \\
\hline Cere batu & $10.6 \pm 2.8$ & $\mathrm{i}$ & $90.3 \pm 36.0$ & $\mathrm{f}$ & $47.0 \pm 30.6$ & $\mathrm{j}$ & $1.9 \pm 0.6$ & $\mathrm{~h}$ \\
\hline Beureum Beunying & $15.6 \pm 2.3$ & $f-i$ & $108.6 \pm 14.8$ & d-f & $85.2 \pm 18.3$ & $f-j$ & $2.9 \pm 0.6$ & $e-h$ \\
\hline Bonbon & $16.3 \pm 3.7$ & $e-i$ & $97.5 \pm 6.7$ & ef & $76.5 \pm 11.5$ & $\mathrm{~h}-\mathrm{j}$ & $3.1 \pm 0.5$ & d-h \\
\hline CV (\%) & 15.91 & & 13.90 & & 21.31 & & 14.78 & \\
\hline
\end{tabular}

$\mathrm{GPB}=$ number of grain per primary branches;

TLSB $=$ total length of secondary branches. Value in the same colom which followed by the same letter was not significantly different based on Tukeys's Honest Significant Difference

Table 5. Correlation among local rice panicle branching observed (Spearman correlation, not all characters were qualify to be analysed with Pearson correlation)

\begin{tabular}{|c|c|c|c|c|c|c|c|c|c|c|c|c|}
\hline & PL & $\mathbf{N N}$ & GNP & NPB & NSB & NTB & PBL & SBL & GPB & GSB & TLPB & TLSB \\
\hline PL & 1.000 & & & & & & & & & & & \\
\hline $\mathrm{NN}$ & $0.139^{\text {ns }}$ & 1.000 & & & & & & & & & & \\
\hline GNP & $0.501^{*}$ & $0.121^{\mathrm{ns}}$ & 1.000 & & & & & & & & & \\
\hline NPB & $0.256^{\mathrm{ns}}$ & $0.370^{\mathrm{ns}}$ & $0.414^{*}$ & 1.000 & & & & & & & & \\
\hline NSB & $0.550^{* *}$ & $0.187^{\mathrm{ns}}$ & $0.974^{* *}$ & $0.503^{*}$ & 1.000 & & & & & & & \\
\hline NTB & $0.111^{\mathrm{ns}}$ & $-0.195^{\mathrm{ns}}$ & $0.514^{*}$ & $-0.377^{\mathrm{ns}}$ & $0.397^{\mathrm{ns}}$ & 1.000 & & & & & & \\
\hline PBL & $0.404^{\mathrm{ns}}$ & $-0.216^{\mathrm{ns}}$ & $0.655^{* * *}$ & $-0.109^{\text {ns }}$ & $0.598^{* * *}$ & $0.620^{* * *}$ & 1.000 & & & & & \\
\hline SBL & $0.072^{\mathrm{ns}}$ & $-0.424^{*}$ & $0.219^{\mathrm{ns}}$ & $-0.398^{\mathrm{ns}}$ & $0.103^{\mathrm{ns}}$ & $0.538^{* * *}$ & $0.723^{* *}$ & 1.000 & & & & \\
\hline GPB & $0.378^{\mathrm{ns}}$ & $-0.114^{\mathrm{ns}}$ & $0.844^{* *}$ & $-0.066^{\mathrm{ns}}$ & $0.769^{* *}$ & $0.816^{* *}$ & $0.858^{* *}$ & $0.538^{* *}$ & 1.000 & & & \\
\hline GSB & $0.235^{\mathrm{ns}}$ & $-0.064^{\mathrm{ns}}$ & $0.527^{* *}$ & $-0.381^{\mathrm{ns}}$ & $0.427^{*}$ & $0.923^{* *}$ & $0.627^{* *}$ & $0.484^{*}$ & $0.823^{* *}$ & 1.000 & & \\
\hline TLPB & $0.593^{* *}$ & $0.181^{\mathrm{ns}}$ & $0.756^{* *}$ & $0.744^{* *}$ & $0.825^{* *}$ & $-0.009^{\text {ns }}$ & $0.468^{*}$ & $0.017^{\mathrm{ns}}$ & $0.429^{*}$ & $0.012^{\mathrm{ns}}$ & 1.000 & \\
\hline TLSB & $0.502^{*}$ & $-0.014^{\mathrm{ns}}$ & $0.910^{* *}$ & $0.160^{\mathrm{ns}}$ & $0.860^{* *}$ & $0.639^{* * *}$ & $0.863^{* *}$ & $0.559^{* *}$ & $0.933^{* *}$ & $0.661^{* *}$ & $0.642^{* *}$ & 1.000 \\
\hline NSBperPB & $0.429^{*}$ & $-0.031^{\mathrm{ns}}$ & $0.861^{* *}$ & $0.0004^{\text {ns }}$ & $0.813^{* *}$ & $0.764^{* *}$ & $0.847^{* *}$ & $0.480^{*}$ & $0.980^{* *}$ & $0.774^{* *}$ & $0.478^{*}$ & $0.935^{*}$ \\
\hline
\end{tabular}

ns: non-significant correlation; ${ }^{*},{ }^{*}$ significant correlation at alpha 0.05 and 0.01 respectively

Some characters showed positive and significant correlation among characters (Table 5). Panicle length had positive and significant correlation with grain number per panicle, number of secondary panicle branches, total length of primary branches, total length of secondary branches, and number of secondary branches per primary branch. It was contrast with study reported by Akinwale et al. and Lakshmi et al. [11,12] that panicle length was not correlated with other characters observed, including number of grain per panicle. Negative and significant correlation was showed at correlation between node number and secodary branch length. The most positive and significant correlation was seen at grain 
number per panicle and number of panicle branches per panicle, number of secondary branches per panicle, number of tertiary branches per panicle, primary branch length, number of grain at primary branches, number of grain at secondary branches, total length of primary branches, total length of secondary branches, and number of secondary branches per primary branch. It was confirmed by the research result by Akinwale et al. [11] that that grain yield was positively corelated with number grain per panicle. Number grain per panicle was determine by components which made up the seed, i.e number of primary branches, number of secondary branches, number of tertiary branches, panicle branches length, grain number per primary branches, grain number of secondary branchis, total length of primary branches, total length of secondary branches, and number of secondary branches per primary branch. Number of primary panicle branches had positive and significant correlation with number of secondary branches and total length of primary branches, while number of secondary branches showed positive and significant correlation with a lot of characters, i.e primary branch length, number of grain at primary branches, number of grain at secondary branches, total length of primary branches, total length of secondary branches, and number of secondary branches per primary branch. Number of tertiary panicle branches also showed positive and significant correlation with primary branch length, secondary branch length, number of grain at primary branches, number of grain at secondary branches, total length of secondary branches, and number of secondary branches per primary branch. Panicle branch length also had positive and significant correlation with secondary branch length, number of grain at primary branches, number of grain at secondary branches, total length of primary branches, total length of secondary branches, and number of secondary branches per primary branch

Secondary branch length had positive and significant correlation with number of grain at primary branches, number of grain at secondary branches, total length of secondary branches, and number of secondary branches per primary branch. While number of grain at primary branches showed positive and significant correlation with number of grain at secondary branches, total length of primary branches, total length of secondary branches, and number of secondary branches per primary branch. Number of grain at secondary branches and total length of primary branches had positive and significant correlation with total length of secondary branches, and number of secondary branches per primary branch, while total length of secondary branches showed positive and significant correlated with number of secondary branches per primary branch.

PCA is an multivariate data analysis to visualize data with scientific maps allows a better understanding of the relation among characters [13]. Dimension I of PCA could explain $55.7 \%$ of variation, while the second one could explain $21.9 \%$. The two dimensions of PCA could explain variation of $77.6 \%$. The next dimension explained $<10 \%$ from total variation. When two PCs had captured most information, the rest of PCs could be ignored and there were no important information lost.

Torres-salinas et al. [13] explained that multivariate data could be represented in a graphical mode as biplot. In a biplot, dots and vectors associated with columns and rows of a matrix to represent elements of data matrix. Based on PCA analysis, the characters which had the same direction, means that those characters showed the positive correlation (Figure 1). While the angle informed to us about the correlation. The smaller the angle, the tighter the correlation. In more deep explanation, the magnitude of correlation among the characters observed could be observed in the magnitude of the angle between two characters [13]. Based on the accessions, the accessions of L16, L02, L07, and L10 were grouped in quadran I. In the second quadran there were the accessions of L03, L09, L04, L11, L12, L14 and L06, while in the third quadran there were L23, L08, L20, L24, L17, L01, L05, and L22. In the quadran IV, there were four accessions, i.e L18, L15, L13, and L19. 
Muthuramu et al. [14] explained that interactioan in PCA was positive when genotype and environment showed the same sign on PCA axis. With the same understanding, when the accessions and the characters observed were in the same sign, it means their interaction was positif. Further, Muthuramu et al. [14] also said that the accessions near the origin was not sensitive to the interactions, while those far away was sensitive.

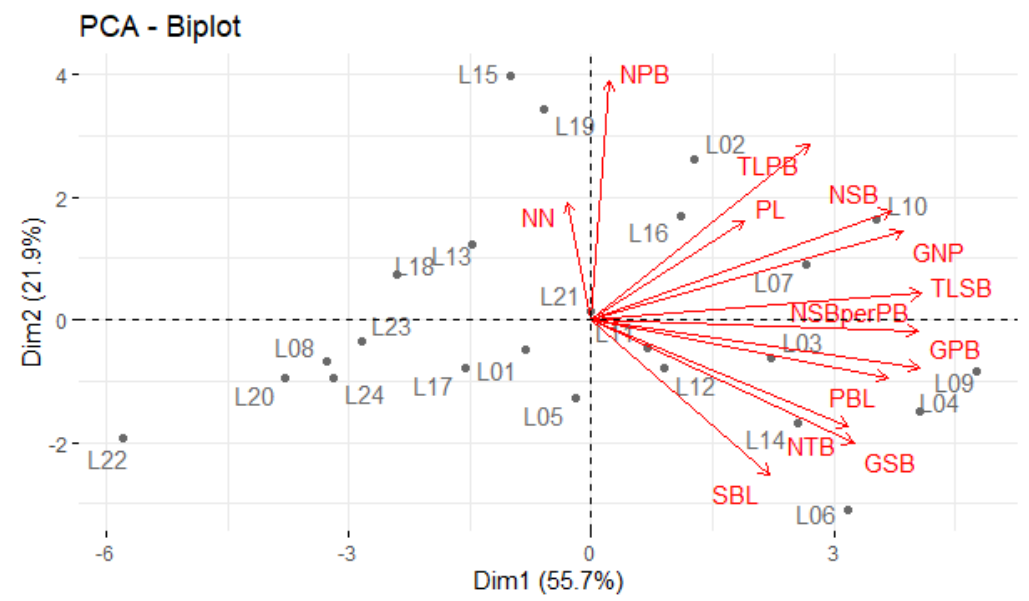

Fig. 1. PCA Biplot of local rice varieties and the panicle branching characters observed

From dendogram, we could see dissimilarity among the accessions tested. The closer distance, the tighter relationship between the accessions. In Figure 2, there were two groups of accessions based on panicle branching characters (all data had been standardized). The first group consisted of 8 members (L13, L08, L17, L22, L18, L23, L20, and L24). While the second group consisted of 16 members (L09, L03, L14, L04, L06, L15, L19, L02, L16, L07, L10, L01, L21, L12, L05, and L11). Detail distance among accessions was presented at Table 6.

The vertical line indicated the genetic distance among the accessions, while the horizontal one indicated the accessions observed. The first group showed that among accessions had closer distance compared with the second one.

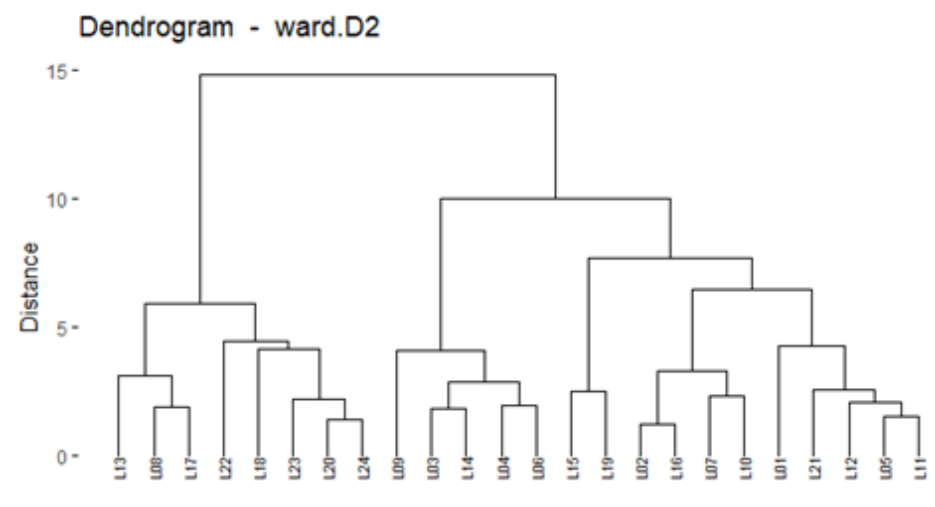

Accessions

Fig. 2. Dissimilarity among West Java local rice varieties based on ward method of clustering of panicle branching characters 
The first group of accessions dominate by the accessions origin from Cisolok, Sukabumi (Cere Batu, Ketan Kidang, Beureum Beunying, Buntut Nyiruan, and Bonbon), while the rest were from Bogor (Apel Bodas), Cianjur (TSP), and Garut (Menet). The domination of Sukabumi's accession was predicted occurred because of its more genetic basis of environment adaption. Xu et al. [15] declare that local varieties of rice had genetic basis of adaptation more extensive than those in improved varieties. Figure 3 and $4 a, 4 b$ showed the architecture of panicle of West Java local rice varieties observed.

The genetic distance among 24 accessions was range from $1.50-10.69$ (Table 6). According to Gasim et al. [16], the broad range of genetic dissimilarity among accessions indicated that there was high degree of dissimilarity among them. Gasim et al. [16] also explained that generally genetic background of local rice varieties was broader than those modern rice cultivar. 


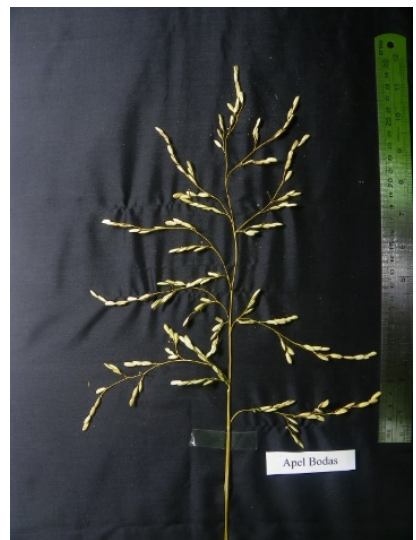

Apel Bodas (L13)

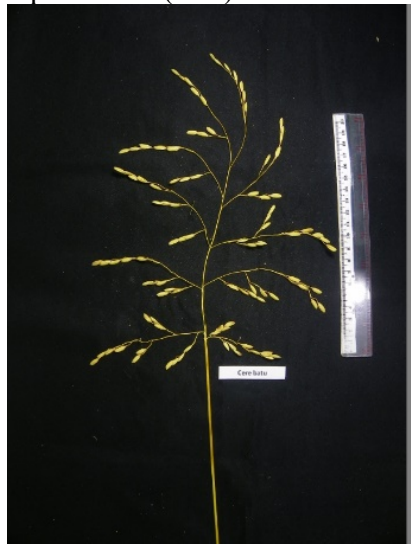

Cere Batu (L22)

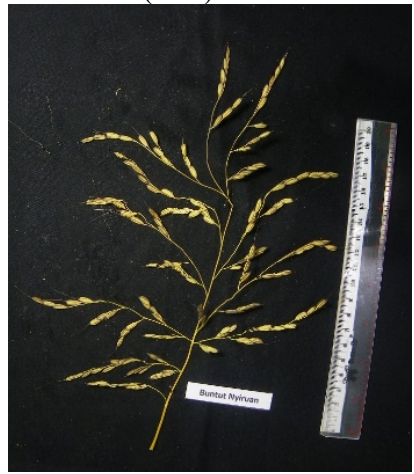

Buntut Nyiruan (L20)

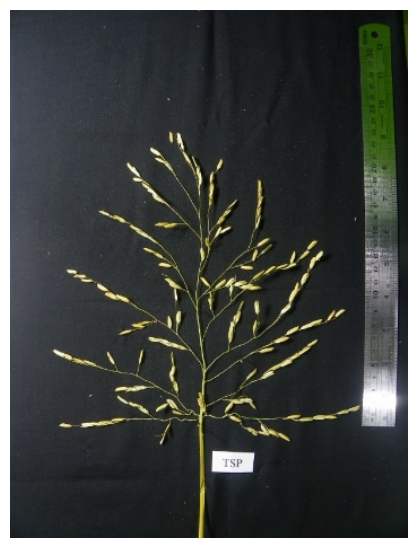

TSP (L08)

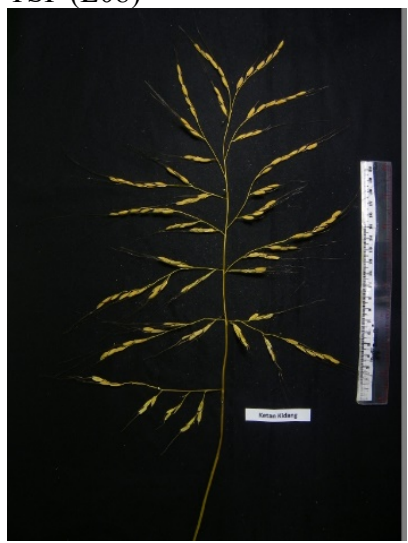

Ketan Kidang (L18)

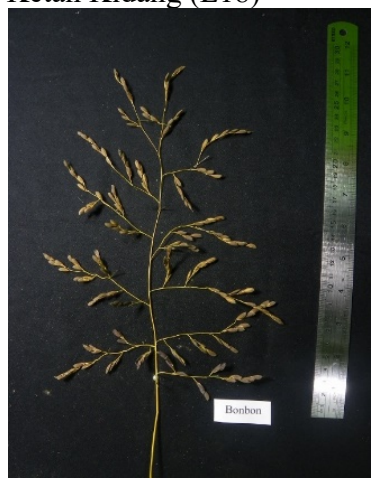

Bonbon (L24)

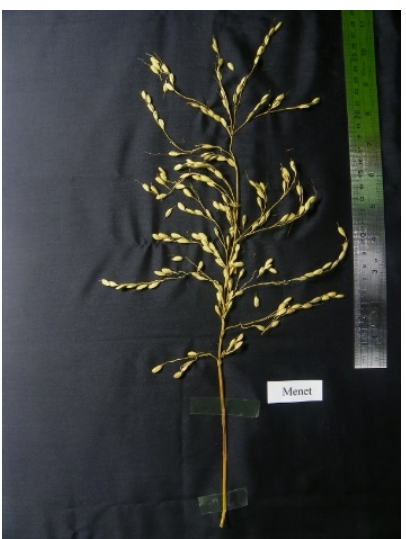

Menet (L17)

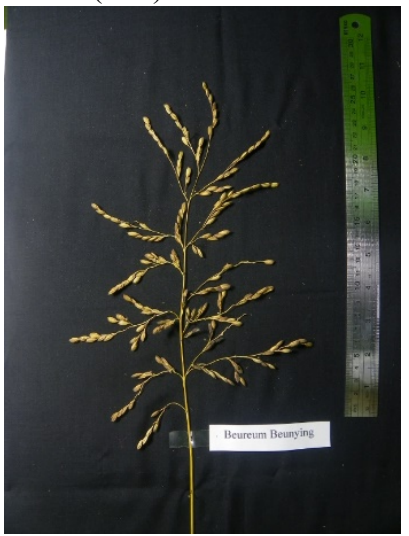

Beureum Beunying (L23)

Fig. 3. Panicle branching performance of West Java local rice accessions from the first cluster 


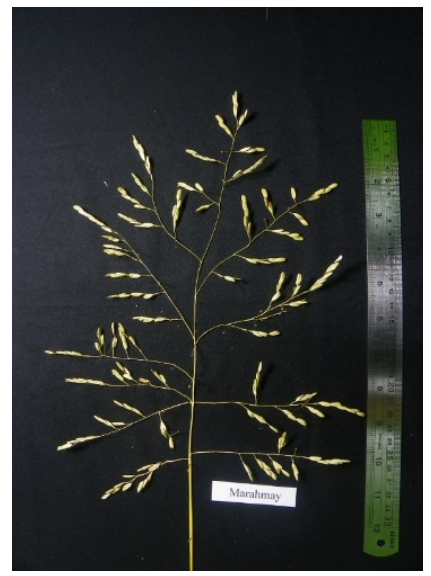

Marahmay (L09)

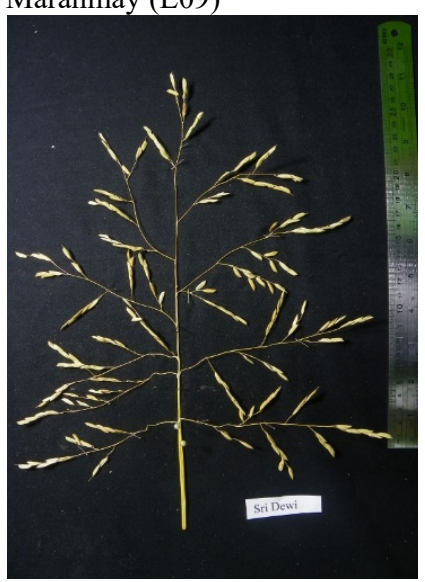

Sri Dewi (L04)

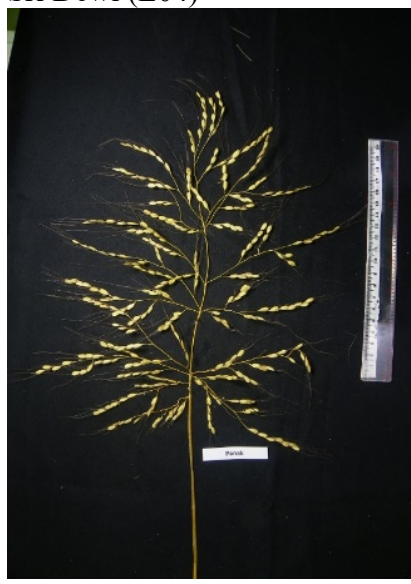

Panak (L19)

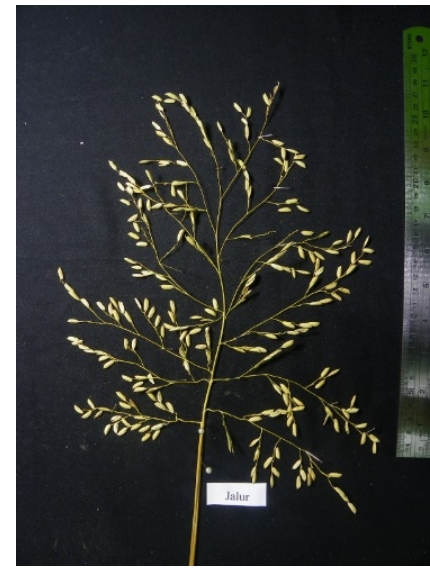

Jalur (L03)

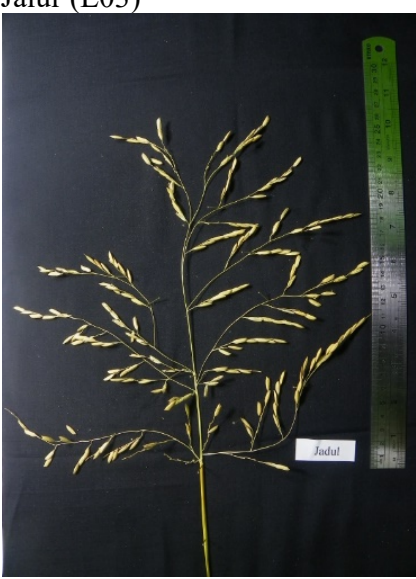

Jadul (L06)

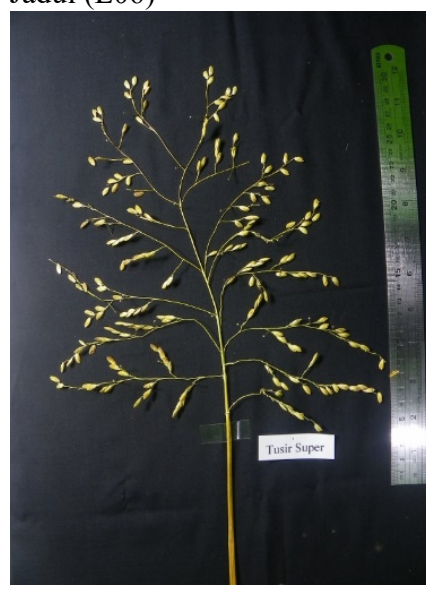

Tusir Super (L02)

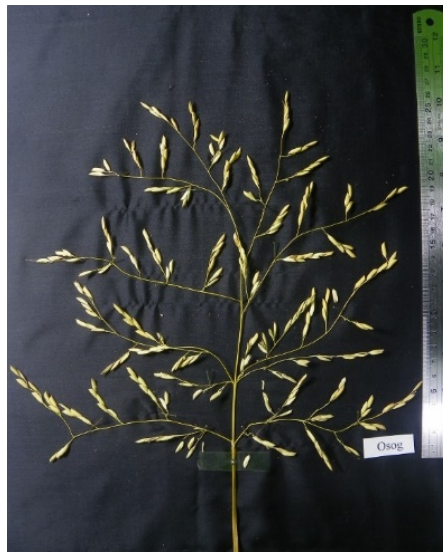

Osog (L14)

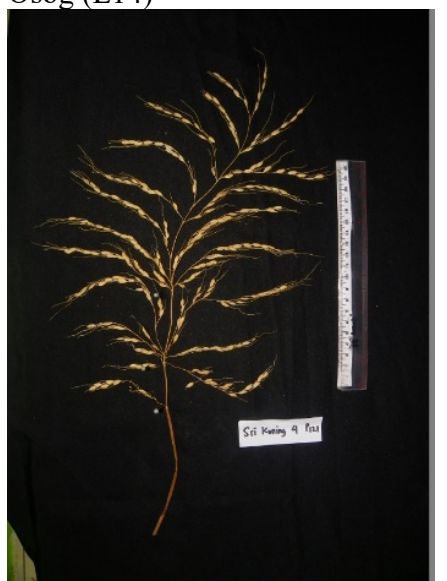

Sri Kuning (L15)

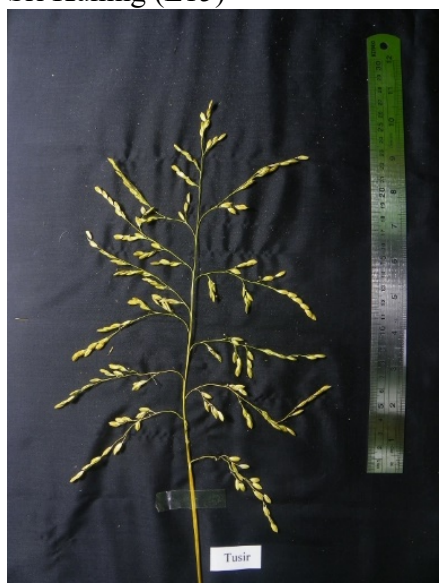

Tusir (L16)

Fig. 4a. Panicle branching performance of West Java local rice accessions from the second cluster 

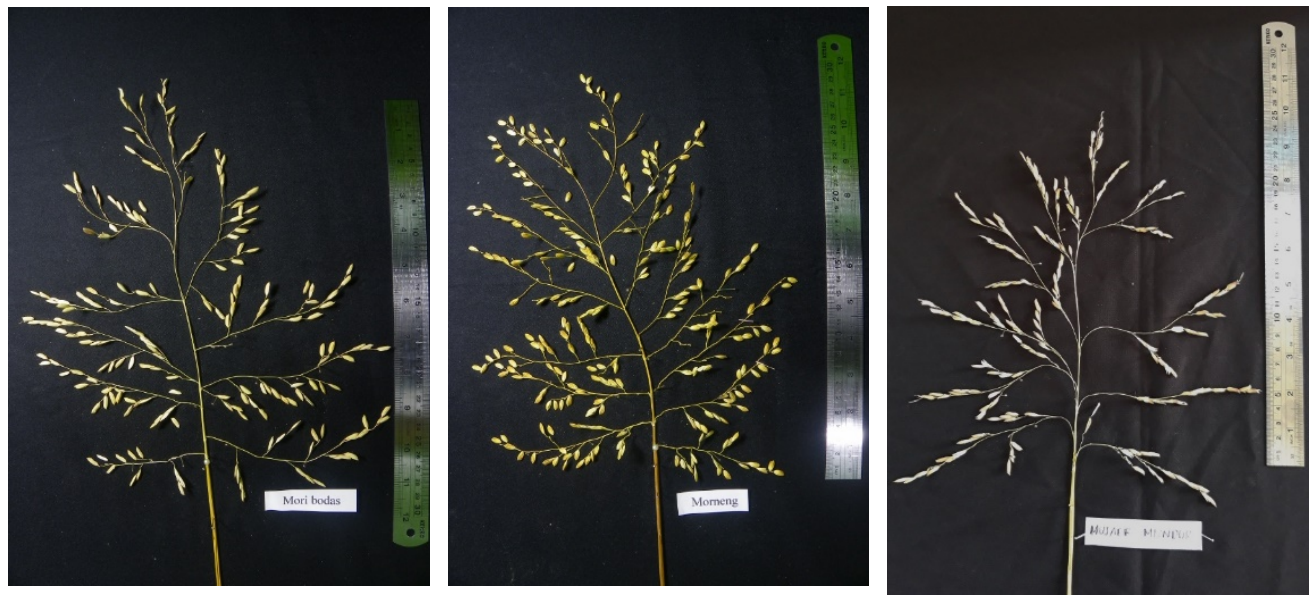

Mori Bodas (L07)

Morneng (L10)
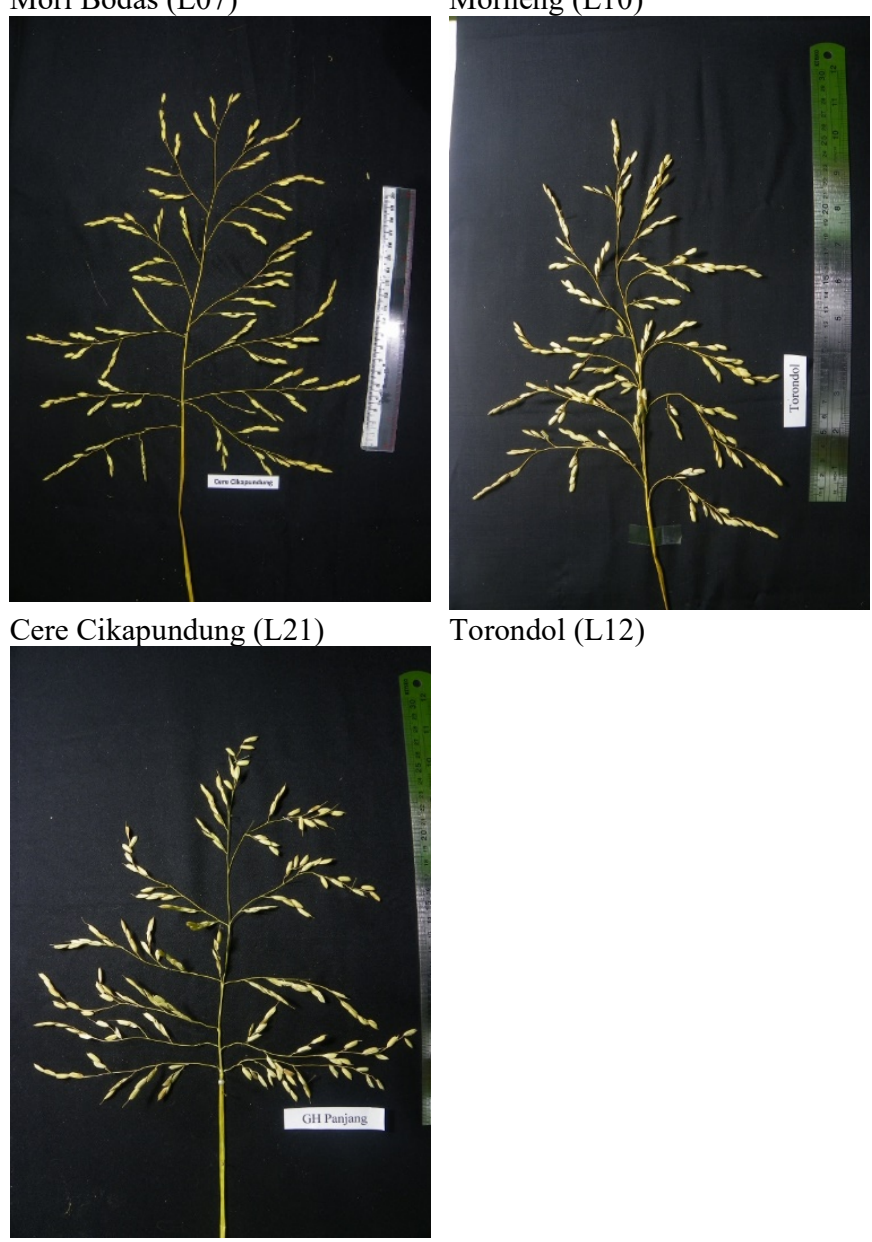

Torondol (L12)

Mujaer Mundur (L01)

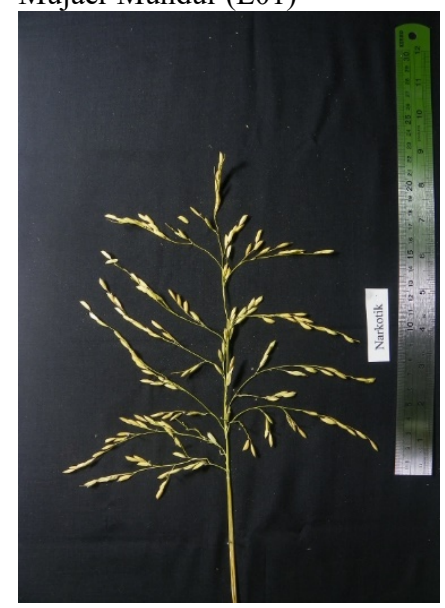

Narkotik (L05)

GH Panjang (L11)

Fig. 4b. Panicle branching performance of West Java local rice accessions from the second cluster (continued) 
Table 6. Distance among the accessions based on panicle branching characteristics

\begin{tabular}{|c|c|c|c|c|c|c|c|c|c|c|c|c|c|c|c|c|c|c|c|c|c|c|c|}
\hline & L01 & \begin{tabular}{|l} 
L02 \\
\end{tabular} & \begin{tabular}{|l} 
L03 \\
\end{tabular} & L04 & L05 & L06 & L07 & \begin{tabular}{|l|l|} 
\\
\end{tabular} & L09 & L10 & L11 & L12 & L13 & \begin{tabular}{|l} 
L14 \\
\end{tabular} & L15 & L16 & L17 & L18 & L19 & L20 & L21 & \begin{tabular}{|l} 
L22 \\
\end{tabular} & \begin{tabular}{|l} 
L23 \\
\end{tabular} \\
\hline L01 & 0.00 & & & & & & & & & & & & & & & & & & & & & & \\
\hline $\begin{array}{l}\text { L02 } \\
\end{array}$ & 4.91 & \begin{tabular}{|l|l}
0.00 \\
\end{tabular} & & & & & & & & & & & & & & & & & & & & & \\
\hline L03 & 4.76 & \begin{tabular}{|l|l|}
3.84 \\
\end{tabular} & 0.00 & & & & & & & & & & & & & & & & & & & & \\
\hline L04 & \begin{tabular}{|l|l}
6.14 \\
\end{tabular} & 5.26 & 2.31 & 0.00 & & & & & & & & & & & & & & & & & & & \\
\hline L05 & 3.32 & $\begin{array}{l}4.32 \\
\end{array}$ & 2.64 & \begin{tabular}{|l|l|}
4.36 \\
\end{tabular} & 0.00 & & & & & & & & & & & & & & & & & & \\
\hline L06 & \begin{tabular}{|l|l|}
6.34 \\
\end{tabular} & 6.37 & 3.10 & 1.97 & 4.22 & 0.00 & & & & & & & & & & & & & & & & & \\
\hline L07 & 4.66 & 2.99 & 1.91 & \begin{tabular}{|l|}
3.10 \\
\end{tabular} & 3.72 & 4.50 & 0.00 & & & & & & & & & & & & & & & & \\
\hline L08 & \begin{tabular}{|l|l|} 
\\
\end{tabular} & 6.26 & \begin{tabular}{|l}
5.73 \\
\end{tabular} & \begin{tabular}{|l}
7.54 \\
\end{tabular} & 3.66 & 7.23 & 6.55 & 0.00 & & & & & & & & & & & & & & & \\
\hline L09 & \begin{tabular}{|l|l|}
7.21 \\
\end{tabular} & 5.79 & 3.72 & \begin{tabular}{|l|l|}
3.11 \\
\end{tabular} & 5.66 & 4.06 & 4.40 & \begin{tabular}{|l|l|}
8.49 \\
\end{tabular} & 0.00 & & & & & & & & & & & & & & \\
\hline L10 & \begin{tabular}{|l|l|}
5.52 \\
\end{tabular} & 2.79 & 3.21 & 3.65 & 4.93 & 5.17 & 2.30 & \begin{tabular}{|l|l|}
7.73 \\
\end{tabular} & 3.65 & 0.00 & & & & & & & & & & & & & \\
\hline L11 & \begin{tabular}{|l|}
3.63 \\
\end{tabular} & 3.43 & 2.00 & \begin{tabular}{|l|}
3.61 \\
\end{tabular} & 1.50 & 3.97 & 2.73 & \begin{tabular}{|l|l}
4.31 \\
\end{tabular} & 5.18 & 3.95 & 0.00 & & & & & & & & & & & & \\
\hline L12 & 3.62 & 3.63 & 2.11 & \begin{tabular}{|l|}
3.61 \\
\end{tabular} & 1.91 & 3.74 & 3.01 & \begin{tabular}{|l|l}
5.17 \\
\end{tabular} & 4.52 & 3.58 & 1.98 & \begin{tabular}{|l}
0.00 \\
\end{tabular} & & & & & & & & & & & \\
\hline L13 & 4.00 & 3.63 & \begin{tabular}{|l|l}
4.24 \\
\end{tabular} & \begin{tabular}{|l|l|}
6.39 \\
\end{tabular} & 2.97 & 6.76 & 4.46 & \begin{tabular}{|l|l}
3.19 \\
\end{tabular} & 6.88 & 5.34 & 3.22 & \begin{tabular}{|l}
3.62 \\
\end{tabular} & 0.00 & & & & & & & & & & \\
\hline L14 & \begin{tabular}{|l|l|}
5.08 \\
\end{tabular} & 4.76 & \begin{tabular}{|l|l}
1.79 \\
\end{tabular} & \begin{tabular}{|l}
1.88 \\
\end{tabular} & 2.97 & 2.16 & 3.23 & \begin{tabular}{|l|l}
6.12 \\
\end{tabular} & 3.10 & 3.73 & 2.57 & 2.42 & \begin{tabular}{|l}
5.11 \\
\end{tabular} & 0.00 & & & & & & & & & \\
\hline L15 & \begin{tabular}{|l|l}
6.79 \\
\end{tabular} & 3.90 & 5.94 & \begin{tabular}{|l}
7.52 \\
\end{tabular} & 5.80 & 8.16 & 5.60 & \begin{tabular}{|l|l}
5.69 \\
\end{tabular} & 7.76 & 5.69 & 5.28 & \begin{tabular}{|l|l}
5.62 \\
\end{tabular} & 3.91 & \begin{tabular}{|l|l}
6.78 \\
\end{tabular} & 0.00 & & & & & & & & \\
\hline L16 & \begin{tabular}{|l|l|}
3.98 \\
\end{tabular} & \begin{tabular}{|l|l}
1.21 \\
\end{tabular} & 2.92 & \begin{tabular}{|l|l|}
4.57 \\
\end{tabular} & 3.32 & 5.57 & 2.21 & \begin{tabular}{|l|l}
5.60 \\
\end{tabular} & 5.30 & 2.61 & 2.50 & \begin{tabular}{|l|l}
2.65 \\
\end{tabular} & 3.04 & \begin{tabular}{|l|}
3.93 \\
\end{tabular} & \begin{tabular}{|l|l|}
4.16 \\
\end{tabular} & \begin{tabular}{|l|l|}
0.00 \\
\end{tabular} & & & & & & & \\
\hline L17 & \begin{tabular}{|l}
4.29 \\
\end{tabular} & 5.19 & \begin{tabular}{|l|l|} 
\\
\end{tabular} & \begin{tabular}{|l|}
5.96 \\
\end{tabular} & 2.22 & 5.83 & 4.96 & \begin{tabular}{|l|l}
1.86 \\
\end{tabular} & 6.93 & 6.29 & 2.87 & \begin{tabular}{|l|l}
3.79 \\
\end{tabular} & 2.42 & \begin{tabular}{|l|l}
4.58 \\
\end{tabular} & 5.51 & \begin{tabular}{|l|l} 
\\
\end{tabular} & 0.00 & & & & & & \\
\hline L18 & \begin{tabular}{|l}
4.84 \\
\end{tabular} & 5.11 & 5.41 & \begin{tabular}{|l}
6.91 \\
\end{tabular} & 4.10 & 6.78 & 5.62 & \begin{tabular}{|l|l}
3.89 \\
\end{tabular} & 8.09 & 6.45 & 4.14 & \begin{tabular}{|l}
4.42 \\
\end{tabular} & $\begin{array}{l}3.77 \\
\end{array}$ & \begin{tabular}{|l|}
5.95 \\
\end{tabular} & \begin{tabular}{|l|}
4.10 \\
\end{tabular} & 4.55 & \begin{tabular}{|l|l}
4.07 \\
\end{tabular} & 0.00 & & & & & \\
\hline L19 & 5.37 & 3.52 & 5.10 & \begin{tabular}{|l|l|} 
\\
\end{tabular} .82 & 4.93 & 7.65 & 4.47 & \begin{tabular}{|l|l} 
\\
\end{tabular} & 7.17 & 5.04 & 4.48 & 4.98 & 3.01 & \begin{tabular}{|l|} 
\\
\end{tabular} & 2.48 & 3.36 & 4.65 & 4.17 & 0.00 & & & & \\
\hline L20 & \begin{tabular}{|l|l|}
4.75 \\
\end{tabular} & 6.24 & 6.18 & \begin{tabular}{|l|l|}
7.88 \\
\end{tabular} & 3.95 & 7.35 & 6.92 & \begin{tabular}{|l|l}
3.32 \\
\end{tabular} & 8.71 & 7.67 & 4.90 & \begin{tabular}{|l|l|}
4.63 \\
\end{tabular} & 3.84 & \begin{tabular}{|l|}
6.44 \\
\end{tabular} & 5.96 & \begin{tabular}{|l|l|}
5.62 \\
\end{tabular} & \begin{tabular}{|l|l|}
3.84 \\
\end{tabular} & 3.24 & 5.91 & \begin{tabular}{|l|l|}
0.00 \\
\end{tabular} & & & \\
\hline L21 & \begin{tabular}{|l|l|}
3.74 \\
\end{tabular} & 3.64 & 2.96 & \begin{tabular}{|l|l|}
4.44 \\
\end{tabular} & 2.39 & 4.72 & 3.09 & \begin{tabular}{|l|l|}
4.32 \\
\end{tabular} & 6.22 & 4.50 & 1.71 & 2.72 & \begin{tabular}{|l}
3.37 \\
\end{tabular} & \begin{tabular}{|l|l}
3.78 \\
\end{tabular} & \begin{tabular}{|l|l|}
4.73 \\
\end{tabular} & \begin{tabular}{|l|l|}
2.78 \\
\end{tabular} & \begin{tabular}{|l|l|}
3.29 \\
\end{tabular} & 2.96 & \begin{tabular}{|l|l|}
4.01 \\
\end{tabular} & 4.60 & \begin{tabular}{|l|l|}
0.00 \\
\end{tabular} & & \\
\hline L22 & 6.43 & 8.46 & 8.06 & \begin{tabular}{|l|}
9.72 \\
\end{tabular} & 5.76 & 8.96 & 8.92 & \begin{tabular}{|l|}
3.51 \\
\end{tabular} & 10.69 & 9.91 & 6.69 & \begin{tabular}{|l|l}
6.84 \\
\end{tabular} & 5.63 & \begin{tabular}{|l|l|}
8.29 \\
\end{tabular} & 7.63 & \begin{tabular}{|l|l|}
7.81 \\
\end{tabular} & \begin{tabular}{|l}
4.88 \\
\end{tabular} & 4.63 & 7.62 & 2.68 & 6.30 & 0.00 & \\
\hline L23 & 3.33 & 5.60 & 5.68 & \begin{tabular}{|l|}
7.36 \\
\end{tabular} & 3.65 & 7.14 & 6.08 & \begin{tabular}{|l|l}
4.01 \\
\end{tabular} & 7.92 & 6.73 & 4.53 & \begin{tabular}{|l|l}
4.07 \\
\end{tabular} & 3.36 & \begin{tabular}{|l|l|} 
\\
\end{tabular} & \begin{tabular}{|l|l|}
5.78 \\
\end{tabular} & \begin{tabular}{|l|l}
4.84 \\
\end{tabular} & 3.90 & 3.48 & 4.99 & \begin{tabular}{|l}
2.29 \\
\end{tabular} & \begin{tabular}{|l|l} 
\\
\end{tabular} & 4.33 & 0.00 \\
\hline L24 & \begin{tabular}{|l|l|}
4.43 \\
\end{tabular} & 5.95 & 5.85 & \begin{tabular}{|l|l|}
7.58 \\
\end{tabular} & 3.67 & 7.12 & 6.62 & \begin{tabular}{|l|l|}
3.67 \\
\end{tabular} & 8.07 & 7.22 & 4.75 & \begin{tabular}{|l|l}
4.21 \\
\end{tabular} & 3.52 & \begin{tabular}{|l|l|}
6.01 \\
\end{tabular} & 5.99 & \begin{tabular}{|l|}
5.30 \\
\end{tabular} & \begin{tabular}{|l|l}
3.78 \\
\end{tabular} & \begin{tabular}{|l|}
3.91 \\
\end{tabular} & 5.71 & \begin{tabular}{|l|l}
1.38 \\
\end{tabular} & \begin{tabular}{|l|l}
4.76 \\
\end{tabular} & 3.69 & \begin{tabular}{|l|l}
1.74 \\
\end{tabular} \\
\hline
\end{tabular}

\section{Conclusions}

There was variation in panicle branching in West Java local rice varieties. Variation occurred as an implication of genetic diversity among accessions. Marahmay and Morneng were the accessions which had the dense panicle and could be choose as promising germplasm to create high yielding varieties. Based on PCA analysis, most of panicle branching characters observed showed the same direction, but among them were not always to be correlated. Based on dendogram, the $24^{\text {th }}$ local rice accessions was divided into two clusters, which the first one had 8 members, i.e TSP (L08), Apel Bodas (L13), Menet (L17), Ketan Kidang (L18), Buntut Nyiruan (L20), Cere Batu (L22), Beureum Beunying (L23), and Bonbon (L24), and second one had 16 members i.e. Mujaer Mundur (L01), Tusir Super (L02), Jalur (L03), Sri Dewi (L04), Narkotik (L05), Jadul (L06), Mori Bodas (L07), Marahmay (L09), Morneng (L10), GH Panjang (L11), Torondol (L12), Osog (L14), Sri Kuning (L15), Tusir (L16), Panak (L19), and Cere Cikapundung (L21). To create a new high yielding rice variety, the rice breeders can select the accessions with more seeds per panicle and more secondary panicle branches.

\section{References}

1. T. Das, A.K. Das, IJTK. 13, 157 (2014)

2. B. Choudhury, M.L. Khan, S. Dayanandan, SpringerPlus. 2, 1 (2013)

3. P.C. Tripathi, Principles, Strategies \& Practices of Exploration, Collection, Characterization, Evaluation \& Cataloging of Plant Genetic Resources Important Fruit Crops Indian Institute of Horticultural Research. (2017)

4. M.S.U. Ahmed, M. Khalequzzaman, M.K. Bashar, A.K.M. Shamsuddin. Rice Sci. 23, $211(2016)$

5. H.D.S. Solís, R.M. Rivera, D.L. David, R.C. Álfarez, Cultivos tropicales. 36, 131 (2015) 
6. W.R. Rohaeni, T. Hastini, Inventarisasi padi lokal di Kawasan Ciater, Subang, Provinsi Jawa Barat, in Prosiding Seminar Nasional Masyarakat Biodiversitas Indonesia, 20 Desember 2014, Depok, Jawa Barat, 1, 189-193 (2015)

7. Nuhasanah, Sadaruddin, W. Sunaryo, Biodiversitas. 18, 1165 (2017)

8. T.K. Kim, KJA. 70, 22 (2017)

9. K. Das, B.B. Panda, B.P. Shaw, S.R. Das, S.K. Das, E. Kariali, P.K. Mohapatra, Sci. Rep. 8, 1 (2018)

10. A.O. Oko, B.E. Ubi, A.A. Efisue, Int. J. Agric. For. 2, 11 (2012)

11. M.G. Akinwale, G. Gregorio, F. Nwilene, B.O. Akinyele, S.A. Ogunbayo, A.C. Odiyi, Afr. J. Plant. Sci. 5, 207 (2011)

12. M.V. Lakshmi, Y. Suneetha, G. Yugandhar, N.V. Lakshmi, IJGEB. 5,121 (2014)

13. Torres-salinas, D.N. Robinson-García, E. Jiménez-contreras, F. Herrera, E.D. LópezCózar, JASIST. 64, 1468 (2013)

14. S. Muthuramu, S. Jebaraj, M. Gnanasekaran, Res. J. Agric. Sci. 2, 98 (2011)

15. Q. Xu, X. Yuan, S. Wang, Y. Feng, H. Yu, Y. Wang, Y. Yang, X. Wei, X. Li, BMC. Genet. 17, 1 (2016)

16. S. Gasim, I. Abuanja, A.W. Abdalla, Afr. J. Agric. Res. 14, 143 (2019) 